\title{
Physicochemical and sensory evaluation of mortadella based on Nile tilapia filleting residues
}

\author{
Paola Casagrande Alda ${ }^{1}$ Melina Franco Coradini ${ }^{1}$ (ib) Ana Paula Sartório Chambo ${ }^{1}$ (D) \\ Stefane dos Santos Correa ${ }^{1}$ (D) Jane Martha Graton Mikcha ${ }^{2}$ (i) Elenice Souza dos Reis Goes ${ }^{3}$ (i) \\ Maria Luiza Rodrigues de Souza ${ }^{* *}$ (1)
}

${ }^{1}$ Programa de Pós-graduação em Zootecnia, Universidade Estadual de Maringá (UEM), Maringá, PR, Brasil.

2Departamento de Análises Químicas e Biomedicina, Universidade Estadual de Maringá (UEM), Maringá, PR, Brasil.

${ }^{3}$ Faculdade de Ciências Agrárias, Universidade Federal da Grande Dourados (UFGD), Dourados, MS, Brasil.

${ }^{4}$ Departamento de Zootecnia, Universidade Estadual de Maringá (UEM), 87020-900, Maringá, PR, Brasil. E-mail: mlrsouza@uem.br. "Corresponding author.

ABSTRACT: The objective of this research was to elaborate and characterize mortadella using fillet residues ('V'-cut fillet trim) of Nile tilapia, in order to add value to this by-product of the filleting process. Three mortadellas were made, one with 100\% tilapia fillet trimmings, another containing $100 \%$ chicken meat and the third with $100 \%$ pork meat. Mortadellae were characterized in terms of microbiology, chemical composition, calcium, collagen, $\mathrm{pH}, \mathrm{Aw}$, colour, texture and formulation cost. Mortadella was within the recommended microbiological standards. Tilapia mortadella had higher levels of moisture, ash, calcium and collagen, higher pH and lower water activity when compared to other species. The tilapia mortadella had lower brightness, higher chroma $a^{*}$ and intermediate chroma $b^{*}$, compared with the others. The texture of tilapia mortadella was better in terms of hardness, gumminess and chewability, the values of which were lower. The chicken mortadella had a higher acceptance rate; however, that of tilapia was also high, while all evaluated attributes of pork received the worst grades. Nile tilapia mortadella is a technological innovation that can be introduced into the food sector with good nutritional value and a good acceptance index.

Key words: fish mortadella, ' $V$ '-cut fillet trim, sensory analysis.

Avaliação físico-química e sensorial de mortadelas a base de resíduos da filetagem de tilápia do Nilo

RESUMO: $O$ objetivo deste trabalho foi elaborar e caracterizar mortadelas a partir de aparas da filetagem (corte em " $V$ " do filé) de tilápia do Nilo, de forma a possibilitar a agregação de valor a este subproduto do processo de filetagem. Foram elaboradas três mortadelas, sendo uma com 100\% de aparas da filetagem de tilápia, outra contendo 100\% de carne de frango e a terceira com 100\% de carne suína. As mortadelas foram caracterizadas quanto à microbiologia, composição química, cálcio, colágeno, pH, Aw, cor, textura e custo de formulação. As mortadelas estavam dentro dos padrões microbiológicos recomendados. A mortadela de tilápia apresentou maiores teores de umidade, cinzas, cálcio e colágeno, maior pH e menor atividade de água quando comparada às demais espécies. A mortadela de tilápia apresentou menor luminosidade, maior croma $a^{*}$ e croma $b^{*}$ intermediário às demais. A textura foi melhor para as mortadelas de tilápia, quanto a dureza, gomosidade e mastigabilidade, cujos valores foram menores. A mortadela de frango teve maior índice de aceitação, porém, a de tilápia também foi elevado, enquanto de suíno todos os atributos avaliados receberam as piores notas. A mortadela de tilápia do Nilo é uma inovação tecnológica que pode ser introduzida no setor alimentício com bom valor nutricional e bom índice de aceitação.

Palavras-chave: mortadela de peixe, aparas do corte em " $V$ ”, análise sensorial.

\section{INTRODUCTION}

Meat products are fundamental constituents of the diets of various populations, providing essential nutrients such as proteins, vitamins and minerals (SALDAÑA et al., 2018). The meat product mortadella is made from an emulsion of meats from one or more species of butcher animals, interspersed with cubes of pork fat (ABREU et al., 2015). In Brazil, mortadella is produced mainly from pork and poultry (MESQUITA et al., 2018). The elaboration of these products from fish meat can be an alternative in the search for tasty foods that are also healthy, since fish is rich in quality lipids and 
highly digestible proteins (BERNADINO FILHO et al., 2019).

In addition to the benefits associated with fish consumption, fish production is a growing sector of the industry. Brazilian fish farming production reached 758,006 tons in 2019, with an emphasis on tilapia, with a production of 432,149 tons (PEIXE BR, 2020). The increase in the industrialization of fish brings with it a rise in the amount of waste; in the case of tilapia, the main product is fillet, generating around $65 \%$ waste comprising the head, carcass, viscera, fins, skin and scales (FONSECA et al., 2020). In addition, filleting generates another residue, as a ' $\mathrm{V}$ '-shaped cut is made to remove the bones that are in the anterior region, close to the lateral line, resulting in filleting residues (SOUZA et al., 2015).

Some of these generated residues can undergo transformation and be marketed and incorporated into human food. In addition, as with Nile tilapia, these residues may present high nutritional value, with proteins of high biological value, vitamins and unsaturated fatty acids and low cholesterol (STEVANATO et al., 2010).

Products like sausages (OLIVEIRA FILHO et al., 2010a), meatballs (OLIVEIRA et al., 2012b), fish burgers (COSTA et al., 2019) and smoked sausage 'mortadella type' (MÉLO, 2011) can be elaborated from fish residues. These products have increased nutritional value, in addition to good sensory acceptance, while their production can provide a greater aggregation of value to this productive chain.

The objective of this research was to elaborate and characterize mortadella using fillet residues ('V'-cut fillet trim) of Nile tilapia, in order to add value to this by-product of the filleting process. The Nile tilapia mortadella was compared with formulations based on chicken and pork meat, and the products were evaluated for their physicochemical, microbiological and sensory characteristics.

\section{MATERIALS AND METHODS}

\section{Processing of mortadella}

The fillet residues ('V'-cut fillet trim) of Nile tilapia (Oreochromis niloticus) used in the elaboration of mortadellas were obtained from the Smartfish company (Rolândia, Brazil). These were frozen immediately after the filleting process and transported in isothermal boxes to the laboratory, where they were stored in a freezer $\left(-18{ }^{\circ} \mathrm{C}\right)$ for 7 days until Nile tilapia mortadella processing. For the processing of chicken mortadella, whole chicken was obtained in the local cold market and deboned, and the chest, thighs, drumsticks and wings were used. For pork mortadella, boneless pork shank, also acquired in a local market, was used. Chicken and pork were kept refrigerated $\left( \pm 5^{\circ} \mathrm{C}\right)$ until the time of analysis. The experiment was carried out in the Fish Technology Laboratory at the Iguatemi (FEI) Experimental Farm, belonging to the State University of Maringá (UEM).

Three mortadellas were elaborated thusly: Tilapia treatment containing 100\% Nile tilapia filleting residue (' $\mathrm{V}$ '-cut fillet trim), Chicken treatment containing 100\% chicken meat and Pork treatment containing $100 \%$ pork meat, with three repetitions per treatment. Mortadella were prepared according to the formulations shown in table 1, where all treatments received the same ingredients in the same proportions.

The fillet residues were previously weighed and ground in a meat grinder (CAF 10, CAF Máquinas, Rio Claro, Brazil), three times using the $3 \mathrm{~mm}$ disc and three times using the $1.5 \mathrm{~mm}$ disc to achieve complete grinding of the bones. The chicken and pork meats were ground only once using a $3 \mathrm{~mm}$ disc. After grinding, the raw materials were homogenized (according to each treatment) in an Arno brand planetary mixer for $20 \mathrm{~min}$, together with the other ingredients (Table 1). After homogenization, the batter was embedded in nylon packages $(80 \mathrm{~mm}$ diameter), tied with nylon clamps of $2.2 \mathrm{~mm} \times 150$ $\mathrm{mm}$ and weighed individually.

The mortadellas were cooked in a steam pan with an internal temperature of $90{ }^{\circ} \mathrm{C}$ until they reached an internal temperature of $72{ }^{\circ} \mathrm{C}$, to accomplish pasteurization of the product and finishing the cooking. The mortadellas of the three species were cooked together, and every $15 \mathrm{~min}$ their positions were rotated inside the steam pan. When they reached the ideal temperature, the mortadellas were submerged in water at $3{ }^{\circ} \mathrm{C}$ to receive a thermal shock for 5 minutes. Once they attained a temperature of $25^{\circ} \mathrm{C}$, the mortadellas were weighed and stored in a refrigerator at $3{ }^{\circ} \mathrm{C}$ until analyses were carried out.

\section{Microbiological analysis}

For microbiological analysis, $100 \mathrm{~g}$ samples from each treatment were analysed for the following aspects: coliforms at $35{ }^{\circ} \mathrm{C}$ and $45{ }^{\circ} \mathrm{C}$, Clostridium sulphite count at $46{ }^{\circ} \mathrm{C}$ and counts of coagulase-positive Staphylococcus and Salmonella sp., as reported by the APHA (2001). 
Table 1 - Formulation of mortadellas of Nile tilapia residues, chicken and pork meat.

\begin{tabular}{|c|c|c|c|}
\hline Ingredients & Nile tilapia residues ${ }^{*}(\%)$ & Chicken (\%) & Pork $(\%)$ \\
\hline Nile tilapia residues & 61.78 & - & - \\
\hline Chicken & - & 61.78 & - \\
\hline Pork & - & - & 61.78 \\
\hline Pork back fat & 20 & 20 & 20 \\
\hline Mix of mortadella Nutron ${ }^{\mathbb{*} * *}$ & 1 & 1 & 1 \\
\hline Salt of cure & 0.25 & 0.25 & 0.25 \\
\hline Salt & 2 & 2 & 2 \\
\hline Flavor enhancer Ajinomoto $^{\circledR}$ & 0.15 & 0.15 & 0.15 \\
\hline Manioc starch & 4 & 4 & 4 \\
\hline Ice & 8 & 8 & 8 \\
\hline Cochineal carmine dye & 0.02 & 0.02 & 0.02 \\
\hline Sugar & 0.5 & 0.5 & 0.5 \\
\hline Condiments $^{* * *}$ & 2.3 & 2.3 & 2.3 \\
\hline
\end{tabular}

", V'-cut fillet trim. ${ }^{* *}$ Mixture of refined salt, antioxidants, stabilizers, essential oils, resin oils and spices.

${ }^{* * *}$ Condiments: pepperoni pepper, ginger powder, nutmeg, powdered onion, fine herbs, saffron powder.

\section{Physicochemical analysis}

Proximate composition, carbohydrates and calcium For analyses of proximate composition, moisture (925.45b), protein (960.52) and ash (923.03) determinations were conducted in triplicate (AOAC, 2005). For lipids, we used the methodology of BLIGH \& DYER (1959). Total carbohydrates were calculated by summing the percentages of all analysed compounds and subtracting from $100 \%$. The mineral solution was prepared by the wet method, according to procedures described by SILVA \& QUEIROZ (2002). The calcium content was determined by flame atomic absorption spectrophotometry according to ZHOU et al. (1998).

\section{pH and water activity}

A digital potentiometer (model MPA-210, Tecnopon, São Paulo, Brazil) and an immersion electrode were used to measure $\mathrm{pH}$.

Water activity analysis (Aw) was performed using the Aw Sprint TH-500 (Novasina Co. Ltd., Talstrasse, Switzerland) Novasina, where three 10 -g aliquots with a standardized temperature of $25^{\circ} \mathrm{C} \pm 1{ }^{\circ} \mathrm{C}$ were placed in the apparatus and read.

\section{Total collagen}

For total collagen analysis, samples from each treatment were ground, homogenized and evaluated by near-infrared (NIR) spectrometry using FoodScanLac equipment (Foss, Hillerød, Denmark) with an artificial neural network calibration model and bench-associated data (AOAC, 2005).

\section{Colour}

The colour of the mortadellas was determined using a Konica Minolta CR-400 colorimeter (Konica Minolta Holdings Inc., Tokyo, Japan) and the CIELAB scale. The light source was the $\mathrm{D} 65$, the observation angle was $10^{\circ} \mathrm{C}$, the aperture of the measuring cells were $30 \mathrm{~mm}$ and the scale of $L^{*}, a^{*}$ and $b^{*}$ was used.

\section{Texture profile analysis}

Texture profile analysis (TPA) was performed using a Brookfield Texture Analyzer CT III (Engineering Laboratories, INC., Middleboro, MA, USA) in the following configurations: the test speed was $1 \mathrm{~mm} / \mathrm{s}$ with a return of $1 \mathrm{~mm} / \mathrm{s}$. The load cell used was $50 \mathrm{~kg}$. Five samples of each treatment were cut into cubes of $20 \mathrm{~mm}^{3}$, and the variables measured for TPA were hardness, cohesiveness, springiness, gumminess and chewiness.

\section{Fatty acid profile}

Fatty acid profiles were established for the mortadellas, and fatty acids were determined according to method 996 of the Association of Official Analytical Chemists (AOAC, 2005).

\section{Sensory analysis}

Sensory evaluation of mortadellas was performed after microbiological analysis. A total of 120 untrained consumers were offered a sample of approximately $20 \mathrm{~g}$ of each treatment to evaluate the 
attributes colour, aroma, texture, flavour and overall acceptance. We used the hedonic scale test, structured in nine points, where 9 represented the maximum grade 'very much liked', and the minimum grade 1, 'disliked very much' (DUTCOSKY, 2007). With these data, we calculated the Acceptability Index (AI) using Formula 1 (DUTCOSKY, 2007):

$$
I A \%=\frac{\text { average score }}{\text { maximum score }} \times 100
$$

Intent to purchase was evaluated using a 5-point scale, where 5 represents the maximum grade (certainly would buy), and 1 represents the minimum grade (certainly would not buy), according DUTCOSKY (2007).

The samples were packed in foil, coded with random three-digit numbers and served simultaneously on disposable white plates. Consumers were instructed to drink water before tasting each sample.

\section{Cost estimate}

The cost estimate for the formulation of mortadellas elaborated with Nile tilapia filleting residues ('V'-cut fillet trim), chicken meat and pork shank was calculated from the sum of the multiplication of the prices of the ingredients by the amount of Nile tilapia, chicken and pork meat at each treatment.

\section{Statistical analysis}

A completely randomized design was used, with three types of mortadella (Nile tilapia mortadella, chicken mortadella and pork mortadella), with three replications per treatment for analysis of chemical composition, $\mathrm{pH}$ and water activity and five repetitions per treatment for physical analysis (texture and instrumental colour). The analyses of calcium, collagen, fatty acid profile and microbiology were only descriptive for the different treatments.

In the statistical analysis, for the results of physicochemical analysis, an analysis of variance (ANOVA) was performed and, in the case of significant differences $(\mathrm{P}<0.05)$, the Tukey test was applied, using Statistical Analysis System software (SAS Inst. Inc. Cary, NC, USA). For the sensory analysis data, the SAS Proc Genmod was used, with distribution of variables as an inverse connection range, taking into account the effects of the treatments and the consumers, at the 5\% significance level.

\section{RESULTS AND DISCUSSION}

\section{Physicochemical analysis}

The results for proximate composition, $\mathrm{pH}$ and water activity are shown in table 2 . There was a significant difference for all evaluated parameters, with the highest moisture content being obtained for Nile tilapia mortadella, followed by chicken mortadella and finally pork mortadella $(\mathrm{P}<0.05)$. The presence of the highest moisture content in Nile tilapia mortadella may have been due to the raw material containing residual water from filleting processing. As the fillet residues were ground frozen to provide further breakage of the spines present in the proximal part of the fillet, the waste water, which was frozen together with the fillet residues, remained in the emulsion. MÉLO et al. (2011) obtained a moisture content above $75 \%$ in mortadella made with minced fish of Nile tilapia, this result being far superior to the one reported in the present study.

Regarding protein content, the Nile tilapia mortadella obtained inferior results to the pork and chicken mortadellas. These results may be related to the higher moisture content of Nile tilapia mortadella. As the moisture content of pork mortadella was lower, there was a higher concentration of protein and lipids and a reduction in carbohydrate content. However, it should be noted that; although, the protein content of tilapia mortadella was lower, fish and its derivatives are distinguished for their high protein content of high biological value, with balanced amino acids (SOUZA et al., 2017). In addition, the digestibility of fish is high, above $95 \%$, and higher than that of meat in general, due to the minimal amount of connective tissue (SOARES \& GONÇALVES, 2012). Similar values to the protein reported in the present study for Nile tilapia mortadella were also reported for sausages produced from meat mechanically separated from Nile tilapia (OLIVEIRA FILHO et al., 2012a).

The mean lipid content of Nile tilapia mortadella was intermediate in relation to the means of chicken and pork mortadella. Fat plays an important role in the manufacturing process, as well as in the sensory and instrumental properties of mortadella texture (SALDAÑA et al. 2015). In sausages made with meat mechanically separated from Nile tilapia, other authors also reported an average close to 5 for the lipid content (OLIVEIRA FILHO et al., 2012a).

Nile tilapia mortadella also had the highest ash content, and this is related to the presence of bones in the residues of tilapia fillet. Ash values of around 3 were also reported for other meat products made with Nile tilapia residues, such as sausages (OLIVEIRA FILHO et al., 2010a OLIVEIRA FILHO et al., 2012a; DALLABONA et al., 2013).

Regarding $\mathrm{pH}$ and water activity (Table 2), there was a significant difference $(\mathrm{P}<0.05)$. The Nile tilapia mortadella had the highest $\mathrm{pH}$, and that of the 
Table 2 - Analysis of the proximate composition, $\mathrm{pH}$, water activity (Aw), calcium and collagen contents of the mortadellas of Nile tilapia residues, chicken and pork meat.

\begin{tabular}{|c|c|c|c|c|}
\hline Parameters & Nile tilapia & Chicken & Pork & P Value \\
\hline Moisture (\%) & $68.01 \pm 0.02 \mathrm{a}$ & $66.51 \pm 0.09 \mathrm{~b}$ & $62.85 \pm 0.03 \mathrm{c}$ & $<0.0001$ \\
\hline Protein (\%) & $15.34 \pm 0.47 \mathrm{c}$ & $16.57 \pm 0.41 b$ & $18.32 \pm 0.62 \mathrm{a}$ & $<0.0001$ \\
\hline Lipid (\%) & $5.11 \pm 0.24 b$ & $3.63 \pm 0.22 \mathrm{c}$ & $10.18 \pm 0.14 \mathrm{a}$ & $<0.0001$ \\
\hline Ash $(\%)$ & $3.14 \pm 0.07 \mathrm{a}$ & $2.77 \pm 0.03 b$ & $2.74 \pm 0.02 b$ & $<0.0001$ \\
\hline Carbohydrate (\%) & $8.40 \pm 0.47 \mathrm{~b}$ & $10.51 \pm 0.49 \mathrm{a}$ & $5.91 \pm 0.740 \mathrm{c}$ & $<0.0001$ \\
\hline $\mathrm{pH}$ & $6.71 \pm 0.01 \mathrm{a}$ & $6.51 \pm 0.01 \mathrm{~b}$ & $6.42 \pm 0.01 \mathrm{c}$ & $<0.0001$ \\
\hline Aw & $0.80 \pm 0.0 \mathrm{c}$ & $0.82 \pm 0.0 \mathrm{a}$ & $0.81 \pm 0.0 \mathrm{~b}$ & $<0.0001$ \\
\hline Calcium $(\mathrm{g} / \mathrm{kg})$ & 2.26 & 0.26 & 0.27 & * \\
\hline Collagen $(\%)$ & 1.22 & 0.98 & 1.57 & * \\
\hline
\end{tabular}

*Descriptive data. Means followed by standard deviation. Mean values in the same line with different letters are significantly different by the Tukey test $(\mathrm{P}<0.05)$.

pork mortadella was significantly lower. Fish have a $\mathrm{pH}$ close to neutrality, higher than that of other meats (SOARES \& GONÇALVES, 2012), a fact that probably contributed to the higher $\mathrm{pH}$ of Nile tilapia mortadella.

Water activity was higher for chicken mortadella and lower for Nile tilapia mortadella. Regardless of the raw material used, mortadella is considered a meat product with low water activity, usually ranging from 0.60 to 0.91 (TAORMINA \& SOFOS, 2014).

Regarding calcium, Nile tilapia mortadella had a higher calcium content than the mortadellas made with chicken and pork, due to the fact that there were bones crushed in the raw material used, and these are rich in calcium (GODOY et al., 2010).

Regarding collagen content, pork mortadella had the highest value, followed by Nile tilapia and poultry mortadella. In food products with a $\mathrm{pH}$ below 7.0 , as in the case of the mortadella in the present study, collagen fibre presents an emulsifying potential, due to the high value of the isoelectric point ( $\mathrm{pH}$ value where a protein has a net electric charge equal to zero) of 6.5 to 8.5, when compared to other protein emulsifiers such as soy, casein and whey protein (SANTANA et al., 2011). Although, collagen is a protein of low biological value (PEARSON \& GILLET, 1999), it is considered important for cooked mortadellas since, after cooking, it is gelatinized, improving the texture of this type of product (GÓMEZ-GUILLÉN et al., 2011). The collagen content reported in Nile tilapia mortadella may be due to the presence of bones in the fillet residues, since Tilapia bone can be a useful source of collagen and gelatine (LIU \& HUANG, 2016).
The results of instrumental colour and texture profile analysis are shown in table 3 . According to the instrumental colour, the mortadellas formulated with chicken meat and pork presented significantly higher brightness $(\mathrm{P}<0.05)$. The chromaticity $\mathrm{a}^{*}$ was higher for the Nile tilapia mortadella $(\mathrm{P}<0.05)$, which was indicated as the one with the greatest red colour, and for $b^{*}$, pork mortadella and Nile tilapia showed more yellowish coloration $(\mathrm{P}<0.05)$. The Nile tilapia mortadella obtained the lowest brightness and higher chromaticity of $\mathrm{a}^{*}$ and of $\mathrm{b}{ }^{*}$ intermediates. Thus, the type of meat and the animal species used may interfere with the brightness of each mortadella, mainly due to the concentration of myoglobin present in meat (BENEDETTI et al., 2011). The low L* of fish mortadella may be due to the fact that tilapia residue is darker in colour than chicken and pork. OLIVEIRA FILHO et al. (2010a) reported the darker colour of meat mechanically separated from tilapia residues, in relation to the fillet. Smoked bologna sausage made with minced fish obtained from waste (parings from the filleting fish operations) of Nile tilapia obtained $\mathrm{L}^{*}$ of 69.08 , chroma $\mathrm{a}^{*}$ of 11.94 and chroma $\mathrm{b}^{*}$ of 11.89 (BARTOLOMEU et al., 2014). MÉLO et al. (2011) elaborated Nile tilapia mortadella based on minced fish including different levels of corn oil and wheat fibre, and obtained values of $\mathrm{L}^{*}=66.39$, $\mathrm{a}^{*}=$ 2.91 and $b^{*}=7.58$ for the control treatment; that is, the product they obtained was lighter and had less intense red and yellow colours than the mortadellas analysed in this study.

In an analysis of instrumental texture (Table 3), the springiness parameter did not differ

Ciência Rural, v.51, n.3, 2021. 
Table 3 - Instrumental colour and texture profile analysis of mortadellas of Nile tilapia residues, chicken and pork meat.

\begin{tabular}{|c|c|c|c|c|}
\hline Parameters & Nile tilapia & Chicken & Pork & P Value* \\
\hline \multicolumn{5}{|c|}{ 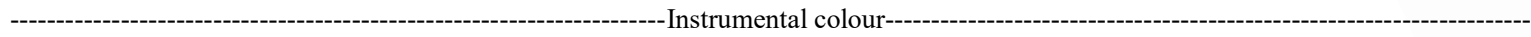 } \\
\hline $\mathrm{L}^{*}$ & $61.51 \pm 0.25 b$ & $64.94 \pm 0.25 \mathrm{a}$ & $64.72 \pm 0.25 \mathrm{a}$ & $<0.0001$ \\
\hline$a^{*}$ & $11.93 \pm 0.12 \mathrm{a}$ & $10.54 \pm 0.12 \mathrm{c}$ & $11.36 \pm 0.12 b$ & $<0.0001$ \\
\hline$b^{*}$ & $9.82 \pm 0.31 \mathrm{ab}$ & $9.44 \pm 0.31 \mathrm{~b}$ & $10.69 \pm 0.31 \mathrm{a}$ & 0.0402 \\
\hline \multicolumn{5}{|c|}{ 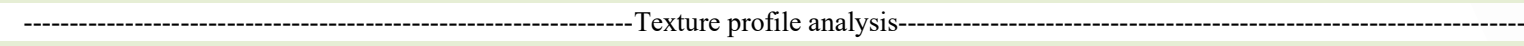 } \\
\hline Hardness $(\mathrm{N})$ & $7.28 \pm 0.52 b$ & $10.18 \pm 1.11 \mathrm{a}$ & $9.54 \pm 0.83 \mathrm{a}$ & 0.0004 \\
\hline Cohesiveness & $0.77 \pm 0.05 \mathrm{a}$ & $0.74 \pm 0.02 \mathrm{ab}$ & $0.70 \pm 0.01 b$ & 0.0163 \\
\hline Springiness (mm) & $4.47 \pm 0.16$ & $4.38 \pm 0.07$ & $4.38 \pm 0.01$ & 0.3176 \\
\hline Gumminess (g) & $573.80 \pm 18.57 \mathrm{~b}$ & $769.60 \pm 97.89 \mathrm{a}$ & $685.00 \pm 61.23 \mathrm{ab}$ & 0.0022 \\
\hline Chewiness (mJ) & $25.18 \pm 1.40 \mathrm{~b}$ & $32.97 \pm 4.78 \mathrm{a}$ & $29.34 \pm 2.62 \mathrm{ab}$ & 0.0088 \\
\hline
\end{tabular}

${ }^{*}$ Means followed by standard deviation and Tukey test at 5\% probability; a, b, c-Mean values in the same line with different letters are significantly different by the Tukey test $(\mathrm{P}<0.05)$.

significantly between the mortadellas of the different animal species $(\mathrm{P}>0.05)$. For hardness, gumminess and chewiness, Nile tilapia mortadella had the lowest averages. The Nile tilapia treatment obtained the highest result for cohesiveness, differing from the treatment with pork, which obtained the lowest result. A possible explanation is that the higher moisture content of tilapia mortadella was responsible for its lower hardness value relative to those of chicken and pork mortadella. In addition, the use of Nile tilapia residues also contributed to the lower hardness, as the increasing addition of mechanically separated meat of tilapia in sausages reduced the hardness from $13.196 \mathrm{~g}$ ( $100 \%$ Nile tilapia fillet) to $881.0 \mathrm{~g}$ (100\% meat mechanically separated meat from Nile tilapia residues) (OLIVEIRA FILHO et al., 2010b).

\section{Fatty acid profile}

The fatty acid profiles of the mortadellas are shown in table 4 . It can be observed that the pork mortadella showed a predominance of saturated (SFA) and monounsaturated fatty acids (MUFA), as well as a higher amount of n-9 fatty acids. The chicken mortadella had the highest sum of polyunsaturated fatty acids (PUFA), besides presenting the highest averages of $n-3$ and $n-6$ series fatty acids. Nile tilapia mortadella presented the lowest average of PUFA, and intermediate means for SFA, MUFA and n-9. This may be related to the addition of pork back fat in all formulations, which altered the fatty acid profile of tilapia mortadella, since the muscle of this species shows total unsaturated fatty acids ranging from $51.7 \%$ to $52.9 \%$, and PUFAs in the range of $27.7 \%$ to $28.6 \%$, eicosapentaenoic acid (C20: $5 \mathrm{n} 3$ ) being the omega 3 present in greatest quantity in the muscle (ADEYEYE, 2011). However, when the $n-6 / n-3$ ratio of all mortadellas was analysed, the tilapia mortadella presented the lowest value (13.13).

In sausage produced with fillet and minced fish derived from Nile tilapia processing, LAGO et al. (2019) reported values of 21.39 for SFAs, 26.39 for MUFAs and 19.82 for PUFAs, and a PUFAs/ SFA ratio of 0.75 , this ratio being higher than that observed in the present study for Nile tilapia mortadella, which was 0.45 .

\section{Microbiological analysis}

According to microbiological analysis of the mortadellas, all products were in accordance with the standards established by the National Agency for Sanitary Surveillance - ANVISA (BRASIL, 2001). All mortadellas presented a result less than 3.0 for the number (NMP)/g of coliforms at $35{ }^{\circ} \mathrm{C}$ and 45 ${ }^{\circ} \mathrm{C}$. For Clostridium sulphite reductant at $46{ }^{\circ} \mathrm{C}$, the result obtained was less than $1 \times 10^{2} \mathrm{NMP} / \mathrm{g}$ and for Staphylococcus coagulase positive, the mortadellas presented values lower than $1 \times 10^{2}$ colony forming units/g, besides the absence in $25 \mathrm{~g}$ of the Salmonellas sp. sample, as recommended by RDC $\mathrm{N}^{\circ} 12$ of January 2, 2001 (BRASIL, 2001). These results indicated that the mortadella was produced under conditions of good hygiene and was suitable for human consumption.

\section{Sensory analysis}

The results obtained in the sensory analysis can be seen in table 5. From the attributes of 
Table 4 - Fatty acid composition (\%) of mortadellas of Nile tilapia residues, chicken and pork meat.

\begin{tabular}{|c|c|c|c|}
\hline Fatty acids $(\%)$ & Nile tilapia & Chicken & Pork \\
\hline \multicolumn{4}{|c|}{ 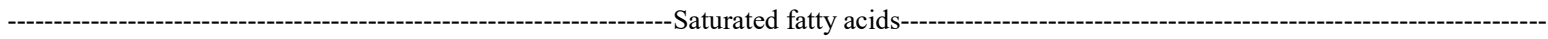 } \\
\hline $\mathrm{C} 10: 0$ & 0.01 & 0.01 & 0.03 \\
\hline C12:0 & 0.01 & 0.02 & 0.02 \\
\hline C14:0 & 0.24 & 0.18 & 0.25 \\
\hline $\mathrm{C} 15: 0$ & 0.02 & 0.01 & 0.02 \\
\hline $\mathrm{C} 16: 0$ & 3.05 & 2.84 & 3.89 \\
\hline $\mathrm{C} 17: 0$ & 0.10 & 0.09 & 0.14 \\
\hline C18:0 & 1.41 & 1.48 & 2.14 \\
\hline C20:0 & 0.03 & 0.02 & 0.03 \\
\hline Sum of saturated fatty acids & 4.87 & 4.65 & 6.51 \\
\hline \multicolumn{4}{|c|}{ 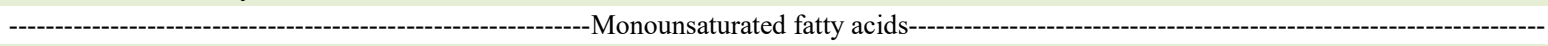 } \\
\hline $\mathrm{C} 16: 1$ & 0.41 & 0.27 & 0.36 \\
\hline $\mathrm{C} 18: \ln 9 \mathrm{t}$ & 0.01 & 0.01 & 0.04 \\
\hline $\mathrm{C} 18: \ln 9 \mathrm{c}$ & 4.73 & 4.49 & 6.51 \\
\hline $\mathrm{C} 20: \ln 9$ & 1.13 & 0.07 & 0.13 \\
\hline Sum of monounsaturated fatty acids & 5.30 & 4.85 & 7.04 \\
\hline \multicolumn{4}{|c|}{ 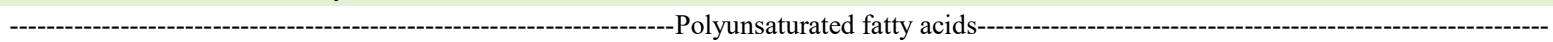 } \\
\hline $\mathrm{C} 18: 2 \mathrm{n} 6 \mathrm{c}$ & 1.80 & 2.49 & 2.38 \\
\hline C18:3n6 & 0.05 & 0.02 & 0.03 \\
\hline $\mathrm{C} 18: 3 \mathrm{n} 3$ & 0.10 & 0.15 & 0.13 \\
\hline $\mathrm{C} 20: 2$ & 0.08 & 0.07 & 0.10 \\
\hline $\mathrm{C} 20: 3 \mathrm{n} 6$ & 0.04 & 0.02 & 0.02 \\
\hline $\mathrm{C} 20: 4 \mathrm{n} 6$ & 0.08 & 0.09 & 0.09 \\
\hline $\mathrm{C} 20: 3 \mathrm{n} 6$ & 0.02 & 0.01 & 0.02 \\
\hline $\mathrm{C} 22: 6 \mathrm{n} 3$ & 0.03 & 0.01 & 0.01 \\
\hline Sum of polyunsaturated fatty acids & 2.20 & 2.87 & 2.79 \\
\hline n-3 n n & 0.15 & 0.18 & 0.16 \\
\hline$n-6$ & 1.97 & 2.62 & 2.53 \\
\hline$n-9$ & 4.88 & 4.58 & 6.67 \\
\hline$n-6 / n-3$ & 13.13 & 14.55 & 15.81 \\
\hline
\end{tabular}

colour, aroma, texture, flavour and overall acceptance of elaborated mortadellas, there was a significant difference $(\mathrm{P}<0.05)$ for all the attributes evaluated in the sensory analysis. As for aroma, texture, flavour, overall acceptance and intent to purchase, the chicken mortadella received significantly higher scores and pork mortadella, the worst scores for all attributes assessed. As for colour, Nile tilapia mortadella received the highest score. Pork mortadella was considered less agreeable among consumers.

Regarding the acceptability index, Nile tilapia mortadella obtained a score of $74.91 \%$ on the acceptability index; that is, the product was considered to be well accepted by the consumer evaluators, since DUTCOSKY (2007) recommends a minimum acceptance score of $70 \%$ for the product to be considered well accepted. Chicken mortadella obtained a general acceptability index of $80.46 \%$. For pork mortadella, the general acceptance percentage of the product was $69.70 \%$; that is, this product did not have a good acceptance score. However, it should be noted that in Brazil, pork products such as salami, ham and mortadella are the only ones that are consumed daily, which is a relatively small share compared to some European countries (BARCELLOS et al., 2011).

It is possible to observe that chicken mortadella had the highest acceptance and also had the lowest lipid content, $3.63 \%$, which demonstrated an inverse correlation between the acceptability index for sensory analysis and lipid content for the mortadella produced in this study. However, a study with tambaqui sausages (Colossoma macropomum) showed greater preference for treatments with a higher percentage of fat (9\%) (SLEDER et al., 2015). 
Table 5 - Sensory analysis, acceptability index and formulation cost of mortadellas of Nile tilapia residues, chicken and pork meat.

\begin{tabular}{|c|c|c|c|c|}
\hline Parameters & Nile tilapia & Chicken & Pork & P Value \\
\hline Colour & $6.78 \pm 1.47 \mathrm{a}$ & $6.71 \pm 1.59 \mathrm{ab}$ & $6.24 \pm 1.71 b$ & 0.0176 \\
\hline Aroma & $6.65 \pm 1.58 b$ & $7.41 \pm 1.34 \mathrm{a}$ & $6.28 \pm 1.81 \mathrm{~b}$ & $<0.0001$ \\
\hline Texture & $6.76 \pm 1.70 \mathrm{ab}$ & $7.16 \pm 1.57 \mathrm{a}$ & $6.43 \pm 1.85 b$ & 0.0048 \\
\hline Flavour & $6.72 \pm 1.77 \mathrm{~b}$ & $7.57 \pm 1.36 \mathrm{a}$ & $6.14 \pm 2.06 \mathrm{c}$ & $<0.0001$ \\
\hline Overall acceptance & $6.80 \pm 1.54 b$ & $7.36 \pm 1.35 \mathrm{a}$ & $6.27 \pm 1.86 \mathrm{c}$ & $<0.0001$ \\
\hline Buy intention ${ }^{*}$ & $3.60 \pm 1.06 b$ & $4.08 \pm 0.92 \mathrm{a}$ & $3.16 \pm 1.27 \mathrm{c}$ & $<0.0001$ \\
\hline A.I. & $74.91 \%$ & $80.46 \%$ & $69.70 \%$ & \multirow{2}{*}{--------Descriptive data--------- } \\
\hline Cost/kg & $\mathrm{R} \$ 14.40$ & $\mathrm{R} \$ 19.07$ & $\mathrm{R} \$ 16.30$ & \\
\hline
\end{tabular}

Means followed by standard deviation and Tukey test at 5\% probability; a, b, c-Mean values in the same line with different letters are significantly different by the Tukey test $(\mathrm{P}<0.05)$. Hedonic scale of nine points; $* 5$-point hedonic scale. A.I. $=$ Acceptability index. $\mathrm{Cost} / \mathrm{kg}=$ formulation $\operatorname{cost} / \mathrm{kg}$.

The 120 consumers who participated in the evaluation were also asked which of the three mortadellas they believed to be made of Nile tilapia. Of their answers, $44.17 \%$ were correct; that is to say, $55.85 \%$ of the public that participated in the sensory analysis did not notice a difference between the chicken and pork species when compared to the Nile tilapia, which had a good general acceptance, as the mortadella elaborated with chicken.

\section{Cost estimate}

In the meat industry, it is advantageous to produce quality foods with a low formulation cost, so that product processing is continuous (CHESNOKOVA et al., 2014). Thus, we estimated the cost of the ingredients use to formulate each treatment, resulting in $\mathrm{R} \$ 14.25 / \mathrm{kg}$ for Nile tilapia mortadella, R\$ 16.15/ $\mathrm{kg}$ for pork mortadella and $\mathrm{R} \$ 18.92 / \mathrm{kg}$ for chicken mortadella. Nile tilapia mortadella presented the lowest formulation cost. This is due to the type of raw material used. If the mortadella had been made from the meat of the Nile tilapia, the cost would have been much higher than that of chicken and pork mortadella. It is important to mention that in Nile tilapia mortadella a type of filleting residue was used, which is usually discarded or underutilized by the fishing industry, which contributed to the reduction of formulation cost and positively influences the reduction of waste generated by the fishing industry.

\section{CONCLUSION}

Residues from Nile tilapia filet ('V'cut fillet trim) can be used in the formulation of mortadella, with good sensory acceptance and satisfactory nutritional and technological profiles. Tilapia mortadella had higher mineral content, especially calcium, greater softness, less luminosity and greater red intensity compared to pork and chicken mortadella. The production of Nile tilapia mortadella provided the food industry with an opportunity for profitable use of such waste.

\section{ACKNOWLEDGEMENTS}

Authors are grateful to Conselho Nacional de Desenvolvimento Científico e Tecnológico (CNPq) $\left(\mathrm{N}^{\mathrm{o}}\right.$ 131596/2016-0), and was financed in part by the Coordenação de Aperfeiçoamento de Pessoal de Nível Superior (CAPES), Brasil Finance code 001

\section{APPROVAL OF THE BIOETHICS AND BIOSECURITY COMMITTEE}

The sensory analysis of mortadellas was approved by the Research Ethics Committee of the State University of Maringá (CAAE: 71048517.2.0000.0104).

\section{DECLARATION OF CONFLICT OF INTERESTS}

The authors declare no conflict of interest. The funding sponsors had no role in the design of the study; in the collection, analyses, or interpretation of data; in the writing of the manuscript, and in the decision to publish the results.

\section{AUTHORS' CONTRIBUTIONS}

PCA and MLRS conceived and designed experiments. PCA, MFC, APSC, SSC and MLRS performed the experiments. PCA, MFC, SSC and JMGM carried out the lab analyses. PCA, 
MLRS and ESRG prepared the draft of the manuscript. All authors critically revised the manuscript and approved of the final version.

\section{REFERENCES}

ABREU, V. K. G. et al. Addition of anacardic acid as antioxidants in broiler chicken mortadella. Food Science and Technology, v.35, n.3, p.539-545, 2015. Available from: <https://www.scielo. br/scielo.php?pid=S0101-20612015005076771\&script $=$ sci arttext>. Accessed: Jun. 23, 2020. doi: 10.1590/1678457X.6771.

ADEYEYE, E. I. Levels of fatty acids, phospholipids and sterols in the skin and muscle of tilapia (Oreochromis niloticus) fish. La Rivista Italiana Delle Sostanze Grasse, v.88, p.4655. 2011. Available from: <https://www.innovhub-ssi.it/c/ document_library/get_file?uuid=17638d6b-4e97-4bc5-ab446e5f82a08996\&groupId=11654>. Accessed: Dec. 09, 2019.

AMERICAN PUBLIC HEALTH ASSOCIATION - APHA. Compendium of methods for the microbiological examination of foods. Washington, DC: APHA, 2001.

ASSOCIATIONS OF OFFICIAL ANALYTICAL CHEMISTS (AOAC). Official methods of analyses of the association of analytical chemists, (18th ed.). Gaithersburg, MD: AOAC, 2005.

BARCELLOS, M. D. et al. Pork consumption in Brazil: challenges and opportunities for the Brazilian pork production chain. Journal on Chain and Network Science, v.11, n.2, p.99-113, 2011. Available from: <https://www.researchgate.net/profile/Federico_ Perez-Cueto2/publication/271064041_Pork_consumption in Brazil Challenges and opportunities for the Brazilian pork_production_chain/links/56054b4908aeb5718ff0ef3f.pdf $>$. Accessed: Jun 26, 2020. doi: 10.3920/JCNS2011.Qpork3.

BARTOLOMEU, D. A. F. S. et al. Storage of vacuumpackaged smoked bologna sausage prepared from Nile tilapia. Acta Scientiarum. Technology, v.36, n.3, p.561567, 2014. Available from: <https://www.redalyc.org/ pdf/3032/303231059024.pdf>. Accessed: Jun. 26, 2020. doi: 10.4025/actascitechnol.v36i3.18263.

BENEDETTI, S. et al. Partial replacement of nitrite by antioxidants and its effect on smoked sausage color. Revista do Instituto Adolfo Lutz, v.70, n.3, p.296-301, 2011. Available from: <http:// www.ial.sp.gov.br/resources/insituto-adolfo-lutz/publicacoes/ rial/10/rial70_3_completa/1377.pdf>. Accessed: Dec. 09, 2019.

BERNADINO FILHO, R. et al. Sensory Evaluation of Shrimp Flavored Nile Tilapia Mortadella. Journal of Experimental Agriculture International, v.38, n.5, p.1-8, 2019. Available from: $<$ https://journaljeai.com/index.php/JEAI/article/view/30310 $>$. Accessed: Oct. 19, 2020. doi: 10.9734/jeai/2019/v38i530310.

BLIGH, E. G.; DYER, W. J. A rapid method of total lipid extraction and purification. Canadian journal of biochemistry and physiology, v.37, n.8, p.911-917, 1959. Available from: <https:// www.nrcresearchpress.com/doi/abs/10.1139/o59-099>. Accessed: Jun. 26, 2020. doi: 10.1139/o59-099.

BRASIL. Ministério da Saúde. Agência Nacional de Vigilância Sanitária. Resolução RDC n. ${ }^{\circ} 12$, de 02 de janeiro de 2001. Regulamento técnico sobre padrões microbiológicos para alimentos. Diário Oficial da União, Brasília, DF, Brasil. 2001.
CHESNOKOVA, A. V. et al. Consumer loyalty as a factor of establishing the competitive advantages in a company under the market conditions. Asian Social Science, v.10, p.255-260, 2014. Available from: <https://pdfs.semanticscholar.org/969c/2563e2e2 95259281acf2b20f5b4de0a7e18e.pdf>. Accessed: Dec. 09, 2019. doi: 10.5539/ass.v10n23p255.

COSTA, D. P. S. et al. Potentiality of using mechanically separated meats of Nile tilapia in fishburgers: chemical, physical and sensory characterization. Brazilian Archives of Biology and Technology, v.62, 2019. Available from: <https:// www.scielo.br/scielo.php?script $=$ sci_arttext\&pid $=\mathrm{S} 1516$ 89132019000100517\&tlng=en>. Accessed: Jun. 24, 2020. doi: 10.1590/1678-4324-2019180436.

DUTCOSKY, S. D. Análise sensorial de alimentos, (2a ed.). Curitiba, PR: Champagnat. 2007.

FONSECA, C. et al. Influence of different waste compositions from tilapia fish on methane production. Journal of Cleaner Production, v.265, p.121795, 2020. Available from: <https://www.sciencedirect. com/science/article/pii/S0959652620318424?casa token=a7UlVhf6 QCcAAAAA:Vosouqb5BMankcBZT2DZSVcsrHh4rT5YFAijMvv_ MQRh1tg2JIjlTukiWQcTNlMnjEy1p1VwSQw\#bib49>. Accessed: Jun. 24, 2020. doi: 10.1016/j.jclepro.2020.121795.

GODOY, L. C. et al. Sensorial analysis of soups and broths made by smoked fish carcasses meal: its utilization to supplement school meals. Ciência e Tecnologia de Alimentos, v.30, p.86-89, 2010. Available from: $<$ http://www.scielo.br/scielo.php?script=sci arttext\&pid $=\mathrm{S} 0101-20612010000500014 \& \operatorname{lng}=\mathrm{en} \& \mathrm{nrm}=\overline{\mathrm{is}}$ o\&tlng=pt $>$. Accessed: Dec. 09, 2019. doi: 10.1590/S010120612010000500014.

GÓMEZ-GUILLÉN, M. C., et al. Functional and bioactive properties of collagen and gelatin from alternative sources: a review. Food Hydrocolloids, v.25, n.8, p.1813-1827, 2011. Available from: <https://www.sciencedirect.com/science/article/ pii/S0268005X11000427>. Accessed: Dec. 09, 2019. doi: 10.1016/j.foodhyd.2011.02.007

LAGO, A. M. T. et al. Shelf life determination of frozen fish sausage produced with fillet and minced fish derived from the Nile tilapia processing. Journal of Food Processing and Preservation, v.43, n.7, p.e13984, 2019. Available from: <https://ifst.onlinelibrary. wiley.com/doi/full/10.1111/jfpp. 13984 ? casa token $=$ Ev 5 p9qKw jKkAAAAA\%3AaAsTrtAuGvRIj55YSJ_xv_d3-Cw43Wyo-6e7 dQbPCzfa 71 kmGzEuu5WqBx3Rgif609YAjtJyy2kvHz6M>. Accessed: Jun. 24, 2020. doi: 10.1111/jfpp.13984.

LIU, H.; HUANG, K. Structural characteristics of extracted collagen from tilapia (Oreochromis mossambicus) bone: effects of ethylenediaminetetraacetic acid solution and hydrochloric acid treatment. International journal of food properties, v.19, n.1, p.63-75, 2016. Available from: <https://www.tandfonline.com/doi/ full/10.1080/10942912.2014.951939>. Accessed: Jun. 24, 2020. doi: $10.1080 / 10942912.2014 .951939$.

MÉLO, H. M. G. et al. Feasibility of using mechanically deboned meat (MDM) of Nile tilapia to produce an emulsified type of sausage. Ars Veterinaria, v.27, n.1., p.022-029. 2011. Available from: $<$ https://pdfs. semanticscholar.org/93ca/fa90be0dabbf3ec7148fb9aab32a71410366. pdf>. Accessed: Dec. 09, 2019.

MESQUITA, E. et al. Capillary electrophoresis to approach sorbate usage in processed meat products in Brazil. Journal of 
food science and technology, v.55, n.1, p.443-447, 2018. Available from: <https://link.springer.com/article/10.1007/s13197-017-29491>. Accessed: Jun. 24, 2020. doi: 10.1007/s13197-017-2949-1.

OLIVEIRA FILHO, P. R. C. et al. Quality of sausage elaborate dusing minced Nile Tilapia submmitted to cold storage. Scientia Agricola, v.67, n.2, p.183-190, 2010a. Available from: $\quad<$ http://www.scielo.br/scielo.php?script=sci_arttext\&pid $=$ S0103-90162010000200009 $>$. Accessed: Dec. 09, 2019. doi: $10.1590 / \mathrm{S} 0103-90162010000200009$

OLIVEIRA FILHO, P. R. C. et al. Elaboration of sausage using minced fish of Nile tilapia filleting waste. Brazilian Archives of Biology and Technology, v.53, n.6, p.1383-1391, 2010b. Available from: $<$ https://www.scielo.br/scielo.php?pid=S151689132010000600015\&script $=$ sci_arttext $>$. Accessed: Jun. 30, 2020. doi: $10.1590 / \mathrm{S} 1516-89132010000600015$.

OLIVEIRA FILHO, P. R. C. et al. Evaluation of physicochemical and sensory properties of sausages made with washed and unwashed mince from Nile tilapia by-products. Journal of Aquatic Food Product Technology, v.21, n.3, p.222-237, 2012a. Available from: $<$ https://www.tandfonline.com/doi/abs/1 0.1080/10498850.2011.590270>. Accessed: Jun. 30, 2020. doi: $10.1080 / 10498850.2011 .590270$

OLIVEIRA, M. C. et al. Microbiological, Physicochemical and Sensory Characteristics of Pulp-of-Tilapia-Based (Oreochromis niloticus) Meatballs. Ciências biológicas e da saúde, v.14, n.1, p.37-44. 2012b. Available from: <https://revista.pgsskroton.com/ index.php/JHealthSci/article/view/1050/1007>. Accessed: Dec. 09, 2019. doi: 10.17921/2447-8938.2012v14n1p\%25p.

PEARSON, A.M.; GILLET, T.A Processed Meat. Gaithersburg: Aspen Publishers, 1999.

PEIXE BR. 2020. Anuário PeixeBR da Piscicultura 2020 (PeixeBR, Ed.). São Paulo. Available from: $<$ https://www.peixebr. com.br/anuario-2020/>. Accessed: Jun. 24, 2020.

SALDAÑA, E. et al. Microstructure, texture profile and descriptive analysis of texture for traditional and light mortadella. Food Structure, v.6, p.13-20, 2015. Available from: <https://www.sciencedirect.com/science/article/abs/pii/ S2213329115000246?via\%3Dihub>. Accessed: Jun. 23, 2020. doi: 10.1016/j.foostr.2015.09.001

SALDAÑA, E. et al. A sensometric approach to the development of mortadella with healthier fats. Meat Science, v.137, p.176-190, 2018. Available from: <https://www.sciencedirect.com/science/ article/pii/S030917401630403X>. Accessed: Jun. 23, 2020. doi: 10.1016/j.meatsci.2017.11.027.
SANTANA, R. C. et al. Emulsifying properties of collagen fibers: Effect of $\mathrm{pH}$, protein concentration and homogenization pressure. Food Hydrocoll, v.25, n.4, p.604-12. 2011. Available from: $<$ https:// www.sciencedirect.com/science/article/pii/S0268005X10001566>. Accessed: Dec. 09, 2019. doi: 10.1016/j.foodhyd.2010.07.018.

SILVA, D. J.; QUEIROZ, A. C. Análise de Alimentos: Métodos Químicos e Biológicos. (3 $3^{\mathrm{a}}$ edição). Universidade Federal de Viçosa. 2002.

SLEDER, F. et al. Development and characterization of a tambaqui sausage. Ciência e Agrotecnologia, v.39, n.6, p.604-612, 2015. Available from: <https://www.scielo.br/scielo.php?pid=S141370542015000600604\&script $=$ sci arttext $>$. Accessed: Jun. 24 2020. doi: 10.1590/S1413-70542015000600007.

SOARES, K. M. P.; GONÇALVES, A. A. Seafood quality and safety. Revista do Instituto Adolfo Lutz, v.71, n.1, p.1-10, 2012. Available from: <http://periodicos.ses.sp.bvs.br/scielo. php?script $=$ sci_arttext\&pid=S0073-98552012000100001\&lng=pt \&nrm=iso\&tlng=pt $>$. Accessed: Jun 24, 2020.

SOUZA, M. L. R. et al. Kaftas prepared with V-shaped filleting chips of the Nile tilapia (Oreochromis niloticus) exposed to smoking techniques. Acta Scientiarum. Technology, v.37, n.2, p.287-291, 2015. Available from: <http://periodicos.uem.br/ojs/ index.php/ActaSciTechnol/article/view/19576/pdf 91>. Accessed Jun. 24, 2020. doi: 10.4025/actascitechnol.v37i2.19576

SOUZA, M. L. R. et al. Formulation of fish waste meal for human nutrition. Acta Scientiarum. Technology, v.39, p.525-531, 2017. Available from: <http://periodicos.uem.br/ojs/index.php/ ActaSciTechnol/article/view/29723> . Accessed Jun. 24, 2020. doi: 10.4025/actascitechnol.v39i5.29723.

STEVANATO, F. B., et al. Evaluation of processing, preservation and chemical and fatty acid composition of Nile tilapia waste. Journal of Food Processing and Preservation, v.34, p.373-383, 2010. Available from: $<$ https://onlinelibrary.wiley.com/doi/full/10 $.1111 / \mathrm{j} .1745-4549.2009 .00429 . \mathrm{x}>$. Accessed: Dec. 09, 2019. doi: 10.1111/j.1745-4549.2011.00624.x.

TAORMINA, P. J.; SOFOS, J. N. Low-water activity meat products. In: The Microbiological Safety of Low Water Activity Foods and Spices. Springer, New York, NY, 2014. p.127-164.

ZHOU, H. Y. et al. Metal concentrations in sediments and Tilapia collected from inland waters of Hong Kong. Water Research, v.32, n.11, p.3331-3340, 1998. Available from: <https://www. sciencedirect.com/science/article/pii/S0043135498001158?casa to ken $=\operatorname{cscXdAOriX4AAAAA:skKI7viLugnbAUEDITVKvGMP}$ RHGzbKtsFcz2dJ1Magq8WXvjxj18mUV TLihAt84GRouuuaAkOY>. Accessed: Jun. 26, 2020. doi: 10.1016/S0043-1354(98)00115-8. 